Fournal of Medical Genetics (1976). 13, 277-280.

\title{
Pfeiffer syndrome: report of a family and review of the literature
}

\author{
YEHEZKEL NAVEH* and ABRAHAM FRIEDMAN \\ From the Department of Paediatrics 'B', Rambam University Hospital and Abba Khoushy School of Medicine, Haifa, Israel
}

Summary. A 5-year-old boy and his father with Pfeiffer syndrome are described. They had acrocephaly, hypertelorism, antimongoloid slant of the palpebral fissures, protrusion of the eyes, large and broad nose, small mandible, irregularly placed teeth, additional upper canine, high-arched palate, partial syndactyly of fingers and toes, brachydactyly of toes, valgus deformity of hypertrophied triangular great toes, broad phalanges of the great toes and broad first metatarsals, accessory epiphyses lateral to the interphalangeal joint of the great toes, and normal intelligence. To our knowledge, this is the first family in which the syndrome is almost totally confined to the head and feet-it spares the upper limbs except for partial skin syndactyly between the fingers-and the third family showing inheritance through three successive generations suggesting an autosomal dominant mode of inheritance. The published papers are reviewed and the clinical and $x$-ray signs are tabulated.

A syndrome of acrocephaly associated with hypertelorism, antimongoloid slant, broad thumbs and great toes, and normal intelligence was first described by Pfeiffer (1964). He reported eight cases through three generations of a family, with two instances of male to male transmission, suggesting an autosomal dominant mode of inheritance. Since then five additional papers describing this syndrome -meanwhile called Pfeiffer syndrome-have been published (Pfeiffer, 1969; Asnes and Morehead, 1969; Zippel and Schüler, 1969; Martsolf et al, 1971; Saldino, Steinbach, and Epstein, 1972).

Recently we have examined a boy and his father who had this syndrome, and because of its rarity and the differences between our cases and those previously described we feel that their presentation is justified.

\section{Case reports}

Case 1. A 5-year-old boy was referred to the paediatric department because of infected traumatic wound of his right ankle.

\footnotetext{
Received 16 May 1975.

* Correspondence and reprint requests to: Dr Yehezkel Naveh, Department of Paediatrics 'B', Rambam University Hospital, Haifa, Israel.
}

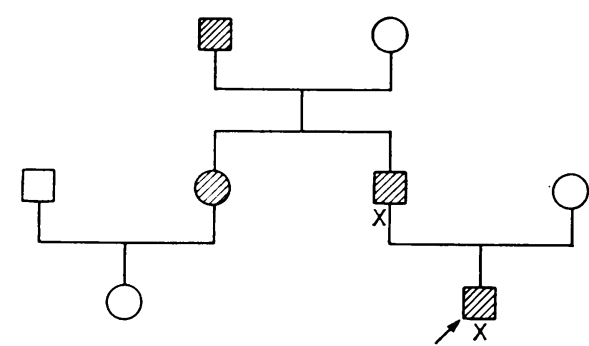

Fig. 1. Family pedigree. Arrow, Proband. $X$, examined by the authors.

Family history. The parents were young and nonconsanguineous. The father had the same syndrome and will be described later as Case 2. The patient's grandfather and aunt allegedly had similar clinical signs to the boy and his father (Fig. 1). All of them were mentally normal. This patient was the only child of his parents.

Perinatal history. Maternal and paternal ages at birth were 30 years. Pregnancy was uneventful and there was no history of illness or exposure to teratogenic agents. The baby was delivered at full term after a normal labour and weighed $2850 \mathrm{~g}$. No neonatal respiratory distress, convulsions, or feeding problems were observed.

Psychomotor development. He sat alone at the age of 8 
months and walked at 1 year. His first sentences were spoken at the age of 2 years. Terman-Merrill tests at 5 years indicated normal intelligence.

Medical history. A year before admission, dacryostenosis was diagnosed and dilatation was made.

Physical examination. The patient was ugly looking.

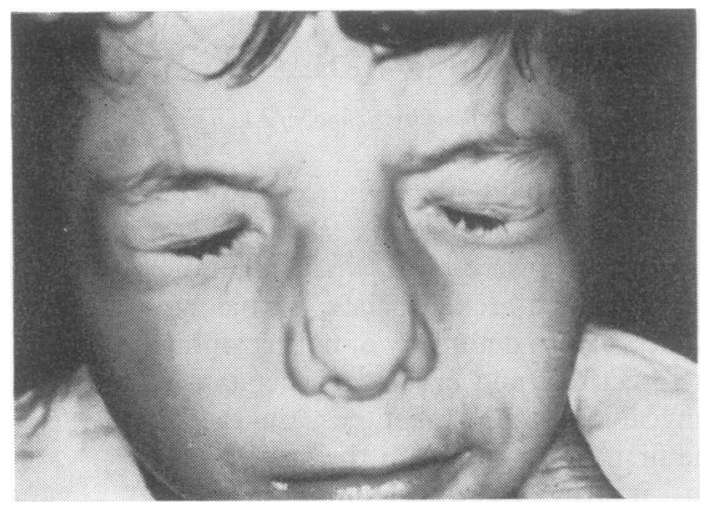

Fig. 2. Case 1. Antimongoloid slant of palpebral fissures, hypertelorism, and large broad nose are prominent.

Temperature $39.7^{\circ} \mathrm{C}$. Head circumference was 49.8 $\mathrm{cm}$ ( $1 \mathrm{SD}$ below the mean). Height was $106.5 \mathrm{~cm}$ and weight $17.5 \mathrm{~kg}$ (both below the 25 th centile for age). The head was acrocephalic with obvious frontal bossing. The face was triangular, with antimongoloid slant of the palpebral fissures, hypertelorism, protruding eyes, large and broad nose, and small mandible (Fig. 2). The palate was high-arched and the teeth irregularly placed. Partial webbing between the second and third fingers of both hands and between the second and third toes of the right foot was seen. The great toes were very broad, hypertrophied, triangular, and tending to valgus position

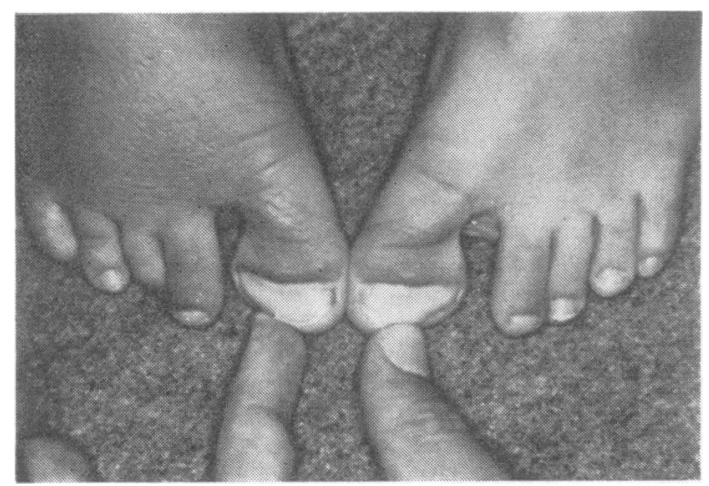

FIg. 3. Case 1. Note broad great toes and partial webbing between the 2 nd and 3 rd toes prominent on the right.
(Fig. 3 and 4). The middle phalanges of all toes seemed shorter than normal especially those of the fourth toes. On the right ankle, an infected wound surrounded by inflamed skin area was noted. Enlarged and tender lymph nodes were palpated in the right groin. This infection was successfully treated with antibiotics.

Laboratory investigation. Complete blood count revealed leucocytosis with shift to the left. Urine and stool examinations were normal. Urinary amino acid chromatography was normal. Urine detection for inborn errors of metabolism with Clinitest (Ames), ferric chloride, dinitrophenylhydrazine, nitroprusside, nitrosonaphthol, cetyltrimethylammonium bromide, ninhydrin, and sulfosalicylic acid gave normal results.

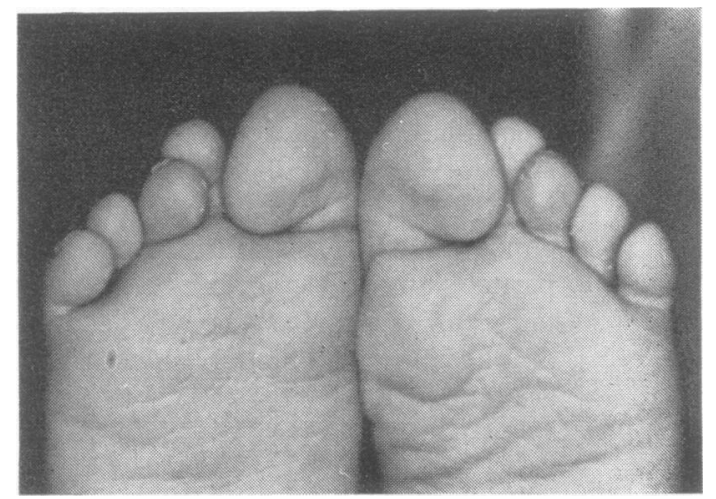

Fig. 4. Case 1. Note hypertrophied triangular great toes tending to valgus position.

$X$-ray examination. Examination of the skull in the posteroanterior and lateral projections showed premature closure of sagittal and coronal sutures, opened lambdoid suture, shallow anterior fossa, increase in the height of cranial cavity, and increased digital markings (Fig. 5 and 6). $X$-ray examination of hands was normal except for partial webbing between the second and the third fingers. $X$-ray pictures of the feet showed a tendency to valgus deformity of the great toes, hypertrophy of the soft tissues of the great toes, accessory epiphyses lateral to the interphalangeal joints of the great toes, broad phalanges of the great toes, broad first metatarsals, and striking shortening of the middle phalanges of the toes (Fig. 7).

Case 2. This patient is the father of Case 1. He is an engineer. On examination, the head was relatively big, acrocephalic with pronounced frontal bossing. The face was triangular with antimongoloid slant of the palpebral fissures, hypertelorism, protruding eyes, large and broad nose, and small mandible similar to his son. The palate was high-arched, the teeth irregularly placed, and an additional right upper canine tooth had erupted in a second row. Partial webbing between the fourth and the 
fifth fingers of both hands and between the fourth and the fifth toes of both feet was noted. The great toes were triangular, hypertrophied, and in a prominent valgus position. Unfortunately photographs and $x$-ray examination were refused.

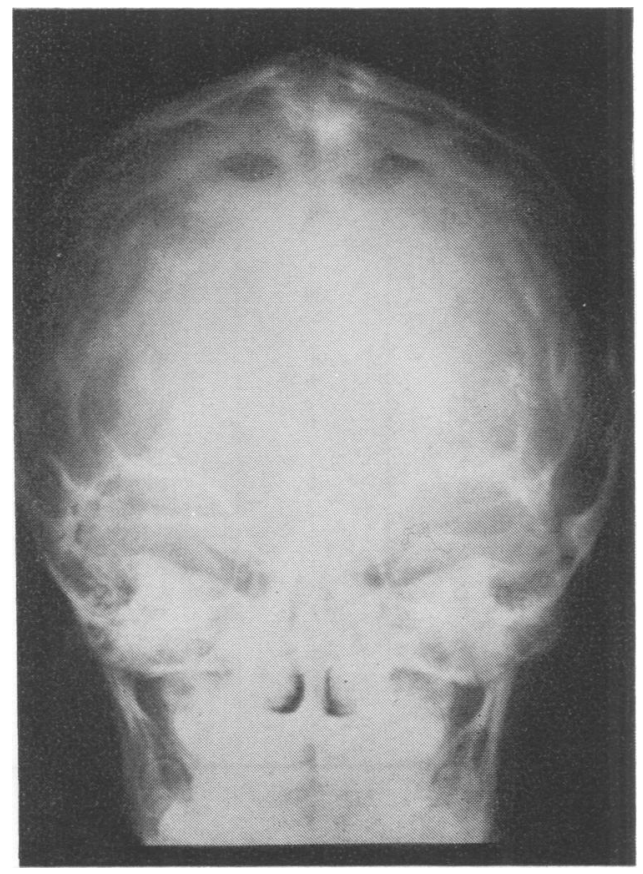

Fig. 5. Case 1. Posteroanterior projection of skull shows premature closure of sagittal and coronal sutures and increased digital markings.

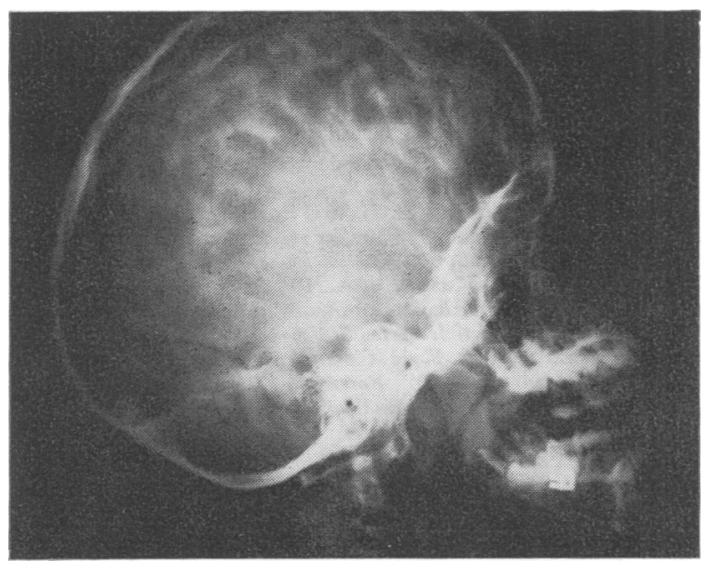

Fig. 6. Case 1. Right lateral projection of skull shows premature closure of coronal suture, opened lambdoid suture, shallow anterior cranial fossa, and increased height of cranial cavity.

\section{Comment}

Temtamy and McKusick (1969) divided acrocephalosyndactyly (ACS) into five types. ACS type I (Apert syndrome); ACS type II (Vogt cephalodactyly); ACS type III (acrocephalosyndactyly with asymmetry of skull and mild syndactyly); ACS type IV (Waardenburg type); and ACS type V (Pfeiffer type).

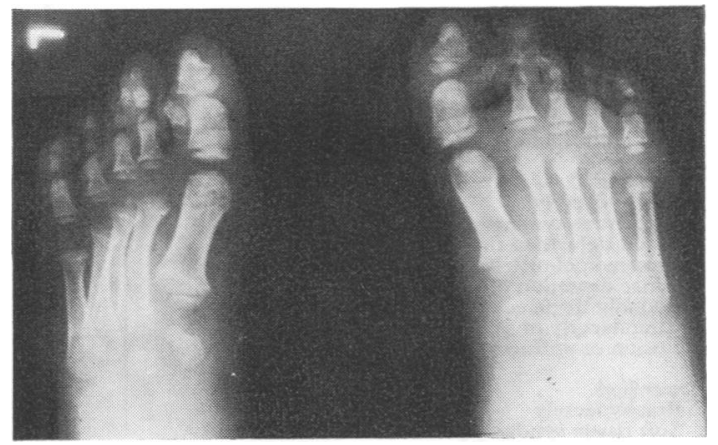

Fig. 7. Case 1. Feet films show soft tissue hypertrophy, tendency to valgus deformity, and an accessory epiphysis lateral to the interphalangeal joint of both great toes, shortening of middle phalanges, broad first metatarsals, and broad phalanges of both great toes.

Our patients have the following characteristics in common with Pfeiffer syndrome: acrocephaly, hypertelorism, antimongoloid slant of the palpebral fissures, protrusion of eyes, large and broad nose, high-arched palate, partial syndactyly of the fingers and toes, deformity of the great toes, brachymesophalanges of toes, broad first metatarsals (proved in Case 1), and normal intelligence.

The Table summarizes the clinical and $x$-ray signs. Because of the great similarity among members of one family suffering from the syndrome, we preferred to consider papers as a whole and not to separate cases. Signs mentioned in one paper only were not included.

As seen in the Table our patients have most of the signs related to the head, face, and lower limbs. In contrast to all other patients, the upper limbs were normal and the only malformation found was partial webbing between the second and the third fingers of both hands. Our patients did not show varus deformity of the great toes such as those described by Pfeiffer (1964), Zippel and Schüler (1969), and Martsolf et al (1971). On the contrary, Case 2 and to a lesser extent Case 1 had valgus deformity. Additional findings noted in both cases were triangular hypertrophied great toes which in Case 1 
TABLE

SUMMARY OF CLINICAL AND RADIOLOGICAL SIGNS IN REPORTED CASES

\begin{tabular}{|c|c|c|c|c|c|c|}
\hline & Pfeiffer & $\begin{array}{c}\text { Asnes } \\
\text { and } \\
\text { Morehead }\end{array}$ & $\begin{array}{l}\text { Zippel } \\
\text { and } \\
\text { Schüler }\end{array}$ & $\begin{array}{c}\text { Martsolf } \\
\text { et al }\end{array}$ & $\begin{array}{l}\text { Saldino } \\
\text { et al }\end{array}$ & $\begin{array}{c}\text { Naveh } \\
\text { and } \\
\text { Friedman }\end{array}$ \\
\hline $\begin{array}{l}\text { Head } \\
\text { Acrocephaly } \\
\text { Hypertelorism } \\
\text { Antimongoloid slant of palpebral fissures } \\
\text { Protrusion of eyes } \\
\text { Flattened nasal bridge } \\
\text { Deformity of nasal bones } \\
\text { Maxillary hypoplasia } \\
\text { Mandible } \\
\text { Irregularly placed teeth } \\
\text { Duplicated upper canines } \\
\text { High-arched palate } \\
\text { Low-set ears } \\
\text { Strabismus } \\
\text { Vision defect } \\
\text { Mental development }\end{array}$ & $\begin{array}{l}+ \\
+ \\
+ \\
+ \\
+ \\
+ \\
+ \\
+ \\
+ \\
+ \\
+ \\
+ \\
+ \\
+\end{array}$ & $\begin{array}{l}+ \\
+ \\
+ \\
+ \\
+ \\
\mathbf{N}\end{array}$ & $\begin{array}{l}+ \\
+ \\
+ \\
+ \\
+ \\
+ \\
+ \\
+ \\
+ \\
+\end{array}$ & $\begin{array}{l}+ \\
+ \\
+ \\
+ \\
\mathbf{P} \\
+ \\
\mathbf{N}\end{array}$ & $\begin{array}{l}+ \\
+ \\
+ \\
+ \\
+ \\
+ \\
\mathbf{S} \\
+ \\
+ \\
+ \\
+ \\
+ \\
+ \\
\mathbf{N}\end{array}$ & $\begin{array}{l}+ \\
+ \\
+ \\
+ \\
\overline{+} \\
\dot{\mathbf{S}} \\
+ \\
+ \\
+ \\
\overline{+} \\
\overrightarrow{+} \\
\overrightarrow{\mathbf{N}}\end{array}$ \\
\hline $\begin{array}{l}\text { Upper limb } \\
\text { Brachydactyly } \\
\text { Soft tissue syndactyly of fingers } \\
\text { Broad deformed thumb } \\
\text { Trapezoidal or triangular 1st phalanx of thumb } \\
\text { Ulnar deviation of proximal phalanx of thumb } \\
\text { Radially deviated terminal phalanges } \\
\text { Clinodactyly of } 5 \text { th digit } \\
\text { Fusion or stiffness of interphalangeal joints }\end{array}$ & $\begin{array}{l}+ \\
+ \\
+ \\
+ \\
+ \\
+\end{array}$ & $\begin{array}{l}+ \\
+ \\
+\end{array}$ & $\begin{array}{l}+ \\
+ \\
+ \\
+ \\
+ \\
+ \\
+ \\
+\end{array}$ & $\begin{array}{l}+ \\
+ \\
+ \\
+ \\
+\end{array}$ & $\begin{array}{l}+ \\
+ \\
+ \\
+ \\
+ \\
+\end{array}$ & $\begin{array}{l}\overline{+} \\
\overline{-} \\
\overline{-} \\
\overline{-}\end{array}$ \\
\hline $\begin{array}{l}\text { Lower limb } \\
\text { Brachydactyly } \\
\text { Soft tissue syndactyly of toes } \\
\text { Broad deformed great toe } \\
\text { Trapezoidal 1st phalanx of great toe } \\
\text { Broad Ist metararsal } \\
\text { Accessory epiphysis of metatarsal } \\
\text { Fusion of tarsal bones } \\
\text { Others } \\
\text { Short stature }\end{array}$ & $\begin{array}{l}+ \\
+ \\
+ \\
+ \\
+\end{array}$ & $\begin{array}{l}+ \\
+\end{array}$ & $\begin{array}{l}+ \\
+ \\
+ \\
+ \\
+ \\
+\end{array}$ & $\begin{array}{l}+ \\
+ \\
+ \\
+ \\
+ \\
+\end{array}$ & $\begin{array}{l}+ \\
+ \\
+ \\
+ \\
+ \\
+ \\
+\end{array}$ & $\begin{array}{l}+ \\
+ \\
+ \\
+ \\
-\end{array}$ \\
\hline
\end{tabular}

$+=$ Present $;-=$ Absent Blank $=$ Unknown; $\mathbf{N}=$ Normal; $\mathbf{P}=$ Prominent $\mathbf{S}=$ Small.

originated from the accessory epiphysis which was lateral to the interphalangeal joint.

Both patients had irregularly placed teeth and the father had an additional upper right canine tooth in a second row. Such dental malformations have been described (Pfeiffer, 1964; Zippel and Schüler, 1969; Saldino et al, 1972).

Review of the published reports up to 1974 revealed only five families. Our family is the third showing transmission of this syndrome through three generations. Appearance of Pfeiffer syndrome in four members of this family in which transmission from male to male was observed twice favours an autosomal dominant mode of inheritance. This fact confirms what has been already suggested (Pfeiffer, 1964; Zippel and Schüler, 1969; Martsolf et al, 1971; Saldino et al, 1972), and has its importance in genetic counselling.
We thank Dr Hiliane Mendelson of our department for help in the preparation of this paper.

\section{REFERENCES}

Asnes, R. S. and Morehead, C. D. (1969). Pfeiffer syndrome. Birth Defects: Original Article Series, 5, 198-203.

Martsolf, J. T., Cracco, J. B., Carpenter, G. G., and O'Hara, A. E. (1971). Pfeiffer syndrome. An unusual type of acrocephalosyndactyly with broad thumbs and great toes. American fournal of Diseases of Children, 121, 257-262.

Pfeiffer, R. A. (1964). Dominant erbliche akrocephalosyndaktylie. Zeitschrift für Kinderheilkunde, 80, 301-320.

Pfeiffer, R. A. (1969). Associated deformities of the head and hands. Birth Defects: Original Article Series, 5, 18-34.

Saldino, R. M., Steinbach, H. L., and Epstein, C. J. (1972). Familial acrocephalosyndactyly (Pfeiffer syndrome). American fournal I of Roentgenology, 116, 609-622.

Temtamy, S. and McKusick, V. A. (1969). Synopsis of hand malformations with particular emphasis on genetic factors. Birth $N$ Defects: Original Article Series, 5, 125-184.

Zippel, H. and Schüler, K. H. (1969). Dominant vererbte Akrozephalosyndaktylie (ACS). Fortschritte auf dem Gebiete der Röntgenstrahlen und der Nuklearmedizin (Stuttgart), 110, 234245. 